\title{
Role of Gender in Work-life Balance
}

\author{
Anjali Jindal ${ }^{1}$, Shivani Agarwal ${ }^{2}$ \\ ${ }^{1}$ Assistant Professor, IILM Graduate School of Management, Greater Noida, \\ ${ }^{2}$ (Corresponding Author) Assistant Professor,KIET School of Management, \\ KIET Group of Institutions, Delhi-NCR, Ghaziabad, India \\ 1jindalanjali1@gmail.com²jindal.shivani24@gmail.com
}

\begin{abstract}
Purpose: Investigating the significant difference in the role of the gender on work-life balance among the employees (managers) in FMCG companies. It is done by assessment of changes in core dimensions of work-life balance.

Design/Methodology/Approach: The assessment was done among 350 managers working in FMCG companies in Delhi/NCR. They had been given questionnaires to make assessment of the dimensions of different variables related to WLB. T-Test were applied to examine the role of gender on WLB.

Findings: The findings suggested significant difference in the exhibition of most of the facets of WLB between the two groups. The hypotheses were validated by the results obtained from the analysis.

Implications/Limitations: The significance has only been validated amongst a limited setup of FMCG managers which gives a conceptual base. It can further be extended to other sectors of public and private companies and to other job roles and services. Various measures of management of employees can further be identified based on this research finding to balance the life and work
\end{abstract}

Index Terms-Work-life Balance, Managers, FMCGs

\section{INTRODUCTION}

$\mathrm{T}$ HE term WLB was first coined in $\mathbf{1 9 8 6}$ to the noxious choices that many Americans were becoming in advance of the workplace, as they chose to ignore family, friends and leisure activities in the quest of business goals. During the 1960s and 1970s, employers believed work life balance mainly an issue for working mothers who grappled with the requirements of theirs jobs and nurturing children. Men began expressing their work life concerns during 1980s. By the end of the 1980s, WLB was more than just women's issues, affecting men, families, organizations, and cultures. WLB is accomplished "when an individual's right to a satisfied life inside and outside paid work is accepted and respected as the norm, to the mutual benefit of the individual, business, and society". (Taken from the Work Foundation)

WLB has been studied in the U.S. since the 1980s and in Europe, primarily the U.K. since the early 1970's (Frone, 2003; Murphy, 1996; Smith \& Gardner, 2007; Stebbins, 2001). Cappelli (2000) asserted that the attention from organizations have been increasing towards the concept of WLB as a result to the need of attracting and retaining competitive employees in a dynamic labor market. Potential personnel no longer remain fully convinced with the remuneration and career aspects of a job. Busi- nesses that help to enhance motivation, satisfaction, commitment, and lessen sources of stress, tend to enhance their capability to recruit and retain worthy employees.

Work life balance has become a concern with the changing environment (Pocock, 2005). In the past, business working hours were quantified in number of hours and minimum leave taken for the period opted for. This creates a dilemma to create a choice between work and family.

Extensively quoted in the prevalent press, the concept of "work-life balance" has gained attention because the view of balance is actually an empowering strategy to deal with spill-over between both the domains (Greenhaus et al., 2003). Previously, the balance was perceived as the absence of conflict (Duxbury, Higgins, \& Lee, 1994). Researchers have found that initiatives related to work-life balance are linked with dynamic programs, seeking at attaining a shift in the corporate culture.

\section{REVIEW OF LITERATURE}

Frone (2003) discussed that the phrase "work-life balance" has received significant consideration and commonly used in everyday language by a numerous of addressees, which makes it difficult to find a generally recognized the term within the work-life literature.

Guest (2002) notes that "balance" in the physical and psychological sense can be defined as "stability of body or mind". He also comments that in the English language, the word balance is often used as a verb and that can imply that it takes agency by the person to manage the balance. Achieving a harmonious integrity in one's work-life balance is an idiosyncratic, complex and ongoing process (Dowdall, 2004; Guest, 2002; Ibarra, 2003; Keene \& Quadagno, 2004; Moody, 1997). It requires an individual's personal leadership (Brown-Klingelhoefer, 2003; Dowdall, 2004; Guest, 2002)

Pitt-Catsouphes, et.al (2006) called "almost taken for granted metaphor". Work-life (family) balance popularly defined in numerous ways (McMillan, Morris, \& Atchley, 2011).

Bailyn, L. (2011) described a work design intervention related to gender equity in their working lives with their personal lives. The Issue showed that potential work with a work-family lens leads to changes in the temporal environment of work, in what has come to be known as flexibility in the workplace 
Todd, P., Binns, J. (2013) recognized that in public sector, WLB as a reason of problem for management in an enhanced quality of working life. The results highlighted the lack of WLB discourse that conceals the tension between the necessary for managers to apply WLB in a more effective manner and the organization are established.

Steven Covey (2004) also supported the significance of work life balance, in his book "The 7 Habits of Highly Effective People”, where he maintains that balance lays the ground work for maintaining the other six habits he recommends for success. Balance requires renewal in the four dimensions that he identifies as physical, mental, social/emotional, and spiritual.

As suggested by Fisher et al. (2001), the present study defines work-life balance as a multi-dimensional construct. In this study, WLB will be measured by Scale developed by Fisher et.al., (2001). The labeling of the three components of the WLB Scale is three dimensions which is explained in detail for a better understanding of the construct. These dimensions are:

1) Work Interference with Personal Life (WIPL): WIPL specifically assessed the degree to which job has a deleterious impact on one's personal life. WIPL includes all time, energy, goal accomplishment and strain.

2) Personal Life Interference with Work (PLIW): It is assessed to the degree to which one's individual's life inhibits with work. Compared to WIPL, PLIW considered the opposite direction of the work/ personal interface: the degree to which aspects of one's personal life have a adverse impact on work.

3) Work/Personal Life Enhancement (WPLE): WPLE assessed the degree to which one's individual's life is augmented by job or vice-versa.

\section{PROPOSED WORK}

The main aim of the proposed work is to assess the significant differences in the WLB of working males and females in NCR region. On the basis of objective hypothesis were developed for the study:

H1- There is a significant difference in the exhibition of the WLB of males and females.

\section{RESEARCH METHODOLOGY}

\section{A. Participants}

The participants were 350 managers from the middle level hierarchy from FMCGs. The questionnaire was accompanied with an instruction note which stated the anonymity of the research. The confidentiality of the responses was also assured to the participants of the study. Researcher has received the completed questionnaires via mail or in-person. Out of 350 respondents, a larger chunk $(70 \%$ ) were males, and 30\% were females. The average age considered of the employee was $40.16(\mathrm{SD}=6.02)$.

\section{B. Procedure}

The significant difference in the WLB based on gender was explored in this study. The scale which was managed in the present study was the self-administered questionnaire. Scale used in this study is discussed in detail. The collection of data was done on the basis of the purposive sampling. Scoring for scale had been done as per the manual's given instructions.

\section{Measure}

To measure WLB, scale developed by Fisher, McAuley, Stanton, Jolton \& Gavin (2001) was used. The instrument comprises of 24 items, capturing the three underlying dimensions of work life balance, to which participants respond using a five-point scale ranging from $1=$ Not at all to $5=$ Almost all the time. WIPL is assessed with twelve items; PLIW is measured with six items. Finally, the third dimension, WPLE is captured by six items.

\section{RESULTS AND Discussion}

The intent of the study was to assess the significant differences in the WLB of the male and female working NCR. Means and standard deviations were calculated for the employees. To test the hypothesis, t-test was used to study the differences.

H1 proposed that WLB perception will vary gender wise. The independent t-test was applied to examined the hypothesis, showed that gender difference exists in the perception towards the work-life balance. The results are presented in the given table show a significant difference exists between the male and female attitudes towards work-life balance $(\mathrm{t}=2.658, \mathrm{df}=348, \mathrm{p}<0.05)$. However, mean scores showed that male employees expressed higher levels of attitude toward work-life balance $(\mathrm{X}=$

TABLE: INDEPENDENT SAMPLE T-TEST FOR (GENDER AND WORK-LIFE BALANCE)

\begin{tabular}{|l|l|l|l|l|l|l|l|}
\hline Gender & $\mathrm{N}$ & Mean & SD & SE Mean & t-value & Df & P value \\
\hline Male & 245 & 28.96 & 5.09 & .33 & & & \\
\cline { 1 - 5 } Female & 105 & 26.50 & 4.59 & .46 & 2.658 & 348 & .008 \\
\hline
\end{tabular}

(SD- Standard Deviation, SE- Standard Error, df- degree of freedom, $\mathrm{p}<0.05$ ) 
28.96) compared to females ( $X=26.50)$. Thus, alternative hypothesis of the study was accepted.

The results indicate that male employees report greater satisfaction (higher mean values) in reference with all the dimensions of WLB as compared to female employees. The findings suggested that there is significant difference between all the dimensions of WLB on the individuals to strike a balance between their work and life.

$\mathrm{H} 1$ suggested that male and female managers perceive WLB differently. WLB from the perspective of gender role has been tested and the results accept the hypothesis which was in constant with many of the earlier studies (Guest, 2002; Halford, 2006; Loscocco, 1997). Reviews from other studies also indicate the same that the perception of WLB to be different across genders (Smithson and Stokoe, 2005).

Hochschild (1997) suggested that one-third of home activities were performed by men and two-thirds were performed by women. Consequently, if there are family conflicts and the woman is making less money than her husband, the woman is more than likely to leave the workplace. It was explained that effective work-life programs such as compressed work weeks, telecommuting, flexible work schedules, job sharing and on-site childcare proved beneficiary to both the employer and the employee, which leads to higher productivity and organizational loyalty (Whittard and Burgess, 2007).

Results indicate that male employees report greater satisfaction (higher mean values) in the perception of WLB as compared to female employees. The working women are exposed to more responsibilities like looking after their commitments towards family, bringing up children, household chores, etc. as well as working in the office to the utmost perfection. This puts some extra burden on them compared to their counterpart men. This disturbs the Work-life balance in women.

\section{CONCLUSION AND FUTURE RESEARCH}

The current study makes significant contribution to knowledge and practice in this field. Demand for WLB varies as per gender variability. Men are hesitant to take flexible working cultures, so when it comes to women, it somehow creates an adverse influence on their careers since managers may doubt their dedication to their professional role. As a result, role of gender in WLB shows more impact for balancing between both the aspects of life and work in women as they need to cater the needs of home, nurturing children etc. This study therefore suggests a definite requirement for the embracing the policies on WLB by the companies, and provide a more flexible working arrangements.

\section{REFERENCES}

[1] Adams, G. A. King, L.A., \& King, D. W. (1996). "Relationship of job and family involvement, family social support and work family conflict with job and life satisfaction". Journal of Applied Psychology, 81(4), 411-420.

[2] Anker, R. (1998). "Gender and jobs: Sex segregation of occupations in the world". Geneva: International Labour Office.

[3] Bacik, Ivana, Costello, Cathryn, \& Drew, Eileen (2003). "Gender In Justice: Feminising the legal professions?" Dublin: Trinity College Dublin Law School.

[4] Bailyn, L. (2011). Redesigning work for gender equity and workpersonal life integration. Community, Work and Family, 14(1), 97112.

[5] Brunton, C. (2006). Work, family, parenting study: Research findings. Ministry of Social Development. Centre for Social Research and Evaluation:Te Pokapu Rangahau Arotaki Hapori.

[6] Cappelli, P. (2000). A market driven approach to retaining talent. Harvard Business Review, 78(1), 103-111.

[7] Connell, R. W. (2005). A really good husband: work/life balance, gender equity and social change. Australian Journal of Social Issues, 40(3), 369-383.

[8] Covey, S. R. (2004). The 7 habits of highly effective people: Restoring the character ethic. New York: Free Press.

[9] Dowdall, J. (2004). How presidents balance work and family. Chronicle of Higher Education, 50, C2-3.

[10] Duxbury, L. E., \& Higgins, C. A. (1991). Gender differences in workfamily conflict. Journal of Applied Psychology, 76(1), 60-73.

[11] Duxbury, L., \& Higgins, C. (2003). Work-life conflict in Canada in the new millennium: A status report. Ottawa: Study Prepared for Health Canada.

[12] Fisher, G. (2001). Work/personal life balance: A construct development study, Dissertation Abstracts International, 002119 August 2001.

[13] Frone, M. R. (2003). Work-family balance. In J.C. Quick and LE Tetrick (Eds.). Handbook of Occupational Health Psychology. (Chapter 7, pp. 143-162). Washington D.C.: American Psychological Association

[14] Greenhaus, J.H., Collins, K.M. and Shaw, J.D. (2003). The relation between work-family balance and quality of life. Journal of Vocational Behaviour, 63, 510-531

[15] Guest, D. E. (2002). Perspectives on the study of work-life balance. Social Science Information, 41(2), 255-79.

[16] Halford, S. (2006). Collapsing the boundaries? Fatherhood, organization and homeworking. Gender, Work \& Organization, 13(4), 383-402.

[17] Hochschild, A. R. (1997). The time bind: When work becomes home and home work. New York: Metropolitan Books.

[18] Ibarra, H. (2003). Working identity: Unconventional strategies for reinventing your career. Cambridge, MA: Harvard Business School Press.

[19] Keene, J. R., \& Quadagno, J. (2004). Predictors of perceived workfamily balance: Gender difference or gender similarity. Sociological Perspectives, 47, 1-23.

[20] Koubova, V., \& Buchko, A. A. (2013). Life-work balance: Emotional intelligence as a crucial component of achieving both personal life and work performance. Management Research Review 36(7), 700-719.

[21] Lilly, J. D., Duffy, J., \& Virick, M. (2006). A gender-sensitive study of McClelland's needs, stress, and turnover intent with workfamily conflict. Women in Management Review, 21(8), 662-680.

[22] Loscocco, K. A. (1997). Work-family linkages among selfemployed women and men. Journal of Vocational Behavior, 50(2), 204-26.

[23] McMillan, H. S., Morris, M. L., \& Atchley, E. K. (2011). Constructs of the work/life interface: A synthesis of the literature and introduction of the concept of work/life harmony. Human Resource Development Review, 10(1), 6-25.

[24] Moody, B. C. (1997). The question of fit: How candidates assess individual-institutional fit before acceping a college or university presidency. Unpublished doctoral dissertation, Harvard University, Cambridge, MA. 
[25] Murphy, L. R. (1996). Stress reduction in work settings: A critical review of health effects. American Journal of Health Promotion, $11,112-135$.

[26] Ostroff, C., \& Bowen, D. E. (2000). Moving HR to a higher level: HR practices and organizational effectiveness. In K. J. Klein \& S. W. J. Kozlowski (Eds.), Multilevel theory, research, and methods in organizations: Foundations, extensions, and new directions (p. 211-266). Jossey-Bass.

[27] Pitt-Catsouphes, M., Kossek, E. E., \& Sweet, S. (2006). Charting new territory: Advancing multi-disciplinary perspectives, methods, and approaches in the study of work and family. In M. Pitt-Catsouphes, E.E. Kossek, \& S. Sweet (Eds.), The zork and family handbook: Multi-disciplinary perspectives and approaches (pp. 1-16). Mahwah, NJ: Lawrence Erlbaum.

[28] Pocock, B. (2005). Work-life balance in Australia: Limited progress, dim prospects. Asia Pacific Journal of Human Resources, 43, 198-209.
[29] Smith, M., Jaffe-Gill, E., \& Segal, R. (2007). Preventing burnout. Signs, symptoms, and strategies to avoid it. Helpguide.org. Retrieved January 30, 2012, from http://www.helpguide.org/ mental/burnout signs symptoms.html

[30] Smithson, J., \& Stokoe, E. H. (2005). Discourses of work-life balance: Negotiating 'genderblind' terms in organizations. Gender, Work and Organization, 12(2), 147-168.

[31] Stebbins L.F. (2001). Work and family in America: A reference handbook. Santa Barbara: ABC-Clio.

[32] Todd, P., \& Binns, J. (2013). Work-life Balance: Is it Now a Problem for Management?. Gender, Work and Organization, 20(3), 219-231.

[33] Whittard, J., \& Burgess, J. (2007). Working-time flexibility and full-time work in a retail banking organisation. Labour \& Industry, 17(3), 119-141. 